\title{
The Classification of Groups Belonging to a Party to an International Armed Conflict
}

\author{
Sondre Torp Helmersen ${ }^{*}$ \\ PhD Research Fellow, University of Oslo, Department of Public and International \\ Law, Faculty of Law. \\ S.T.Helmersen@cantab.net
}

\begin{abstract}
It has been argued that groups of fighters who "belong" to a party to an international armed conflict without fulfilling the requirements of Article 4(A)(2) of Geneva Convention III should be classified as combatants, rather than as civilians. This article questions the reasoning put forward in support of that view, by showing that the arguments may be partly circular, incomplete, and debatable.
\end{abstract}

\section{Keywords}

International armed conflict; direct participation; civilians; combatants; classification; belonging; responsibility

\footnotetext{
* I thank Gaiane Nuridzhanian for inspiration, support, and comments, and Niccolò Ridi and Stian Øby Johansen for fruitful discussions.
} 


\section{Introduction}

This article concerns the classification of a specific group of fighters in armed conflicts: fighters who are members of a group that "belongs" to a party to an international armed conflict (IAC) in line with Article 4(A)(2) of Geneva Convention III (GC III), ${ }^{1}$ yet do not comply with all the requirements listed in that provision. The mainstream view seems to be that these fighters should be classified as combatants, despite the apparent wording of GC III. This article aims to show that the main arguments advanced to support this view are unsatisfactory, and that the question is more complex than what has been hitherto assumed.

The topic in question is part of a more general debate about civilians taking a direct part in hostilities; a debate covering multiple disputed points. Therein, arguments have arisen over e.g. what it means to "belong" to a party to a conflict; whether members of groups taking a direct part in hostilities should be classified as combatants, civilians, or something else; what it means to take a direct part in hostilities; how long the loss of civilian protection lasts; what it takes to regain civilian protection; whether there is a principle of "least harm" towards civilians taking part in hostilities; and how the classification of individuals may affect the classification of relevant conflicts. ${ }^{2}$ The current article concerns a narrow question within this more general debate, which has so far been dealt with only briefly, if at all, by previous contributions.

The question of classification raised in this article is relevant to many real life conflicts, contemporary and historical. In the Vietnam War, the non-State group

\footnotetext{
${ }^{1} 1949$ Geneva Convention Relative to the Treatment of Prisoners of War (Third Geneva Convention), 75 UNTS 135.

${ }^{2}$ These issues and opposing views are addressed in e.g. International Committee of the Red Cross (ICRC), Interpretive Guidance on the Notion of Direct Participation in Hostilities under International Humanitarian Law (2009). As it relies more an academic sources than on State practice, this publication is different from the ICRC's more general and comprehensive customary humanitarian law study: J.-M. Henckaerts and L. Doswald-Beck (eds.), Customary International Humanitarian Law: Volume I: Rules (2005) and J.-M. Henckaerts and L. Doswald-Beck (eds.), Customary International Humanitarian Law: Volume II: Practice (2005).
} 
Vietcong can be said to have "belonged" to the State of North Vietnam, which fought an IAC with the United States of America and South Vietnam. ${ }^{3}$ As part of the conflicts that ravaged the Former Yugoslavia from 1991 to 1999, the Republika Srpska, a non-State entity, was argued to belong to (what remained of) the Federal Republic of Yugoslavia in its IAC with Bosnia and Herzegovina. ${ }^{4}$ The Second Congo War (1998-2003) included at least one IAC wherein various non-State armed groups assisted both parties to the conflict. ${ }^{5}$ The 2001 invasion of Afghanistan gave rise to an IAC between the Taliban government of Afghanistan and the United States of America (with its allied forces), with Al-Qaida, a non-State armed group, considered by some as belonging to the former. ${ }^{6}$ The non-State Kurdish Peshmerga forces assisted in the United States-led invasion of Iraq in 2003. In 2008, during the IAC between Russia and Georgia, non-State actors in Abkhazia and South Ossetia fought on the Russian side, and in doing so could arguably be considered as belonging thereto. ${ }^{7}$ In 2011, the Libyan Civil War reached the threshold of an IAC between Gaddafi's regime and the intervening international coalition of States, with the antiGaddafi rebel factions potentially belonging to the latter. ${ }^{8}$ In the 2014 Russian

\footnotetext{
${ }^{3}$ See e.g. H. Meyrowitz, 'The Law of War in the Vietnamese Conflict', in R. A. Falk (ed.), The Vietnam War and International Law, Vol. 2516 (1969), at 538; T. Hoffmann, 'Squaring the Circle? International Humanitarian Law and Transnational Armed Conflicts', in M. J. Matheson and D. Momtaz (eds.), Rules and Institutions of International Humanitarian Law Put to the Test of Recent Armed Conflicts: Les règles et les institutions du droit international humanitaire à l'épreuve des conflits armés récents 217 (2010), at 240.

${ }^{4}$ Judgment, Prosecutor v. Duško Tadić, IT-94-1-A, International Criminal Tribunal for the former Yugoslavia, Appeals Chamber, 15 July 1999, at para. 162.

5 The classification of this conflict is discussed by L. Arimatsu, 'The Democratic Republic of the Congo 1993-2010', in E. Wilmshurst (ed.), International Law and the Classification of Conflicts 146 (2012), at 176-181.

${ }^{6}$ This possibility is suggested by e.g. Y. Arai-Takahashi, 'Disentangling Legal Quagmires: The Legal Characterisation of the Armed Conflicts in Afghanistan since 6/7 October 2001 and the Question of Prisoner of War Status', 5 Yearbook of International Humanitarian Law 61 (2002), at 66.

${ }^{7}$ P. Leach, 'South Ossetia' (2008), in E. Wilmshurst (ed.), International Law and the Classification of Conflicts 317 (2012), at 332-338 tentatively classifies this as two separate conflicts, although admitting that the facts remain unclear.

${ }^{8}$ K. Mačák and N. Zamir, 'The Applicability of International Humanitarian Law to the Conflict in Libya', 14 International Community Law Review 403 (2012), at 422-423 conclude that the rebels did not belong to the coalition. M. Milanovic and V. Hadzi-Vidanovic, 'A taxonomy of armed conflict', in
} 
invasion of Ukraine armed non-State actors in Donetsk and Luhansk continue to participate alongside Russia, while other militias, including the Right Sector group, fight with the Ukrainian government. ${ }^{11}$ As such, the arguments presented in the present article would affect the rights and obligations of such non-State groups. As discussed in section 4 below, the classification of these groups would under current law not affect their absence of civilian protection, but it would affect whether they are entitled to prisoner of war status and combatant immunity.

This article will first locate the debate in question within the framework of current international humanitarian law (section 2). Examples of the mainstream argument are subsequently presented in section 3. Section 4 then presents two counterarguments, namely that the mainstream view is partly circular and that it does not take full account of the consequences of the different classifications. Finally, section 5 addresses a possible solution to the issue identified, based on Article 43 of Additional Protocol I (AP I) ${ }^{14}$. Section 6 provides a conclusion.

\section{The Issue}

The (international) law of armed conflict distinguishes between two types of conflict: international armed conflict and non-international armed conflict. Most sources agree that there are no further categories of armed conflict. ${ }^{15}$ This article concerns the status of certain fighters in IACs.

N. D. White and C. Henderson (eds.), Research Handbook on International Conflict and Security Law 256 (2013), at 277 assume the same.

${ }^{11}$ Whilst Russia denies involvement in the Donbass War, NATO, amongst others, has considered the formers participation in the military operations in Eastern Ukraine to be a fact. See e.g. http://www.nato.int/cps/en/natohq/news_112695.htm?selectedLocale=en (last accessed 6 December 2014).

141977 Protocol Additional to the Geneva Conventions of 12 August 1949, and relating to the Protection of Victims of International Armed Conflicts (First Additional Protocol), 1125 UNTS 3.

${ }^{15}$ See e.g. ICRC, How is the Term "Armed Conflict" Defined in International Humanitarian Law (2008) at 1; J. Kleffner, 'Scope of Application of International Humanitarian Law' in D. Fleck (ed.), The Handbook of International Humanitarian Law 43 ( $3^{\text {rd }}$ edition, 2013), at 44; M. Milanovic and V. Hadzi-Vidanovic, supra note 8, at 303-4; N. Melzer, Targeted Killing in International Law (2008), at 
The rules of international law that regulate IACs distinguish between different categories of persons. As such, the primary distinction is that between combatants and civilians, which are to be considered as being mutually exclusive. ${ }^{16}$ Combatants have the right to participate in hostilities, ${ }^{17}$ and are entitled to prisoner of war status on capture by the enemy (Article 44(1) of AP I). Civilians are entitled to civilian protection, e.g. from being targets of acts of war (Article 51(2) of AP I and Article 13(2) of Additional Protocol II (AP II)). Civilians who do take a direct part in hostilities however, lose this protection for the duration of their direct participation in hostilities (Article 51(3) of AP I and Article 13(3) of AP II). ${ }^{18}$

In light of the definition of civilians in Article 50 of AP I, combatants are defined negatively therein as "any person who [belongs] to one of the categories of persons referred to in Article 4 A (1), (2), (3) and (6) of the Third Convention and in Article 43 of this Protocol". Article 43 of AP I concerns "[t]he armed forces of a Party to a conflict". These are to be considered combatants, even if they have non-combat roles. ${ }^{19}$ Article $4(\mathrm{~A})$ of GC III lists various categories of individuals, who under Article 50 of AP I will be classified as combatants. The present article concerns Article 4(A)(2), which covers "other militias and members of other volunteer corps [...] belonging to a party to the conflict". Under Article 4(A)(2) these are entitled to prisoner of war status "provided that [they] fulfil" four specified conditions:

262-269; Judgment, Hamdan v. Rumsfeld, 548 U.S. 557, Supreme Court of the United States, 29 June 2006, at 67-68.

${ }^{16}$ E.g. Melzer, supra note 11, at 310; Judgment, Anonymous v. State of Israel, Criminal Appeal 6659/06, Supreme Court of Israel, 11 June 2008, at 13-14.

${ }^{17}$ More precisely they have "combatant immunity", which bars prosecution and punishment of their regular acts of war by foreign States. This is seen e.g. in Chapter III of GIII, particularly in the rule in Article 82 that prisoners of wars (i.e. enemy combatants) can be subject to judicial punishment only for acts that would also be illegal for the detaining power's own forces.

181977 Protocol Additional to the Geneva Conventions of 12 August 1949, and relating to the Protection of Victims of Non-International Armed Conflicts (Second Additional Protocol), 1125 UNTS 609.

${ }^{19}$ According to J.-M. Henckaerts and L. Doswald-Beck (eds.), Customary International Humanitarian Law: Volume I: Rules (2005), at Rule 3, only " medical and religious personnel" of armed forces are exempt from combatant status. 
a) "being commanded by a person responsible for his subordinates";

b) "having a fixed distinctive sign recognizable at a distance";

c) "carrying arms openly"; and

d) "conducting their operations in accordance with the laws and customs of war"

Accordingly, this article concerns fighters who belong to a party to an IAC, but who do not fulfil one or more of these four conditions. ${ }^{20}$ As with all other persons in an IAC, these fighters must be classified as either combatants or civilians. According to Article 4(A)(2) itself, the four conditions are cumulative, and thus, if one or more is not fulfilled, the fighters in question do not qualify for prisoner of war status. Under Article 50 of AP I, this would mean that since they do not fall within the definition provided in Article 4(A)(2), they are not to be considered combatants, but rather as civilians. Mainstream academic literature has, however, taken the opposite stance, as presented in the following section.

\section{Mainstream Arguments}

According to the ICRC's Interpretive Guidelines, fighters who belong to a party to an IAC without fulfilling the criteria in Article 4(A)(2) of GC III should be classified as combatants rather than civilians:

Strictly speaking, however, these requirements constitute conditions for the post-capture entitlement of irregular armed forces to combatant privilege and prisoner- of-war status and are not constitutive elements of the armed forces of a party to a conflict.

Thus, while members of irregular armed forces failing to fulfil the four requirements may not be entitled to combatant privilege and prisoner-ofwar status after capture, it does not follow that any such person must necessarily be excluded from the category of armed forces and regarded as a civilian for the purposes of the conduct of hostilities. On the contrary, it would contradict the logic of the principle of distinction to place irregular armed forces under the more protective legal regime afforded to the civilian population merely because they fail to distinguish themselves

\footnotetext{
${ }^{20}$ The text will assume that at least one of the conditions is not fulfilled, and does not discuss their content in any further detail.
} 
from that population, to carry their arms openly, or to conduct their operations in accordance with the laws and customs of war. Therefore, even under the terms of the Hague Regulations and the Geneva Conventions, all armed actors showing a sufficient degree of military organization and belonging to a party to the conflict must be regarded as part of the armed forces of that party. ${ }^{21}$

A similar argument is made by Akande:

[I]t must be remembered that article 4 of GCIII was not drafted for the purpose of the law relating to targeting or the conduct of hostilities. That provision addresses itself to prisoner of war status and issues relating to internment and detention of combatants. There is a distinction between the rules relating to the targeting, rules relating to detention and those relating to prosecution. A person may be classified differently depending on the purposes for which classification is being made. A member of an organized armed group that belongs to a State who falls outside the scope of application of GCIII will fall within the scope of the Fourth Convention (which is titled as the Convention Relative to the Protection of Civilian Persons in Time of War-GCIV). However, the protections accorded such a person under that latter Convention deal mainly with fundamental rules of humane treatment as well as rules relating to internment. Coming within the scope of the Fourth Convention does not necessarily mean that a person is not to be regarded as a combatant for the purposes of the conduct of hostilities. One would suspect that State practice bears this out and that States do not consider themselves to be more restricted when it comes to targeting irregular groups that belong to a State but which do not comply with article 4(A)(2) of GCIII. Indeed, it would be a very odd situation, if members of irregular groups that do not comply with the rules of international law concerning distinction, or with the laws and customs of more generally, thereby gain additional protections from targeting because they are now regarded as civilians for the purpose of the law relating to the conduct of hostilities. ${ }^{22}$

The reasoning seems to be that the fighters in question are violating their obligations under international humanitarian law when taking part in hostilities, and should not be "rewarded" with civilian status therefore. ${ }^{23}$ This builds on two premises: (1) that the

\footnotetext{
${ }^{21}$ ICRC, supra note 2, at 22 (footnotes omitted).

${ }^{22}$ D. Akande, 'Clearing the Fog of War? The ICRC's Interpretive Guidance on Direct Participation in Hostilities', 59 International and Comparative Law Quarterly 180 (2010), at 184 (footnotes omitted).

${ }^{23}$ M. Schmitt, 'The Interpretive Guidance on the Notion of Direct Participation in Hostilities: A Critical Analysis', 1 Harvard National Security Journal 5 (2010), at 18 calls the argument "accurate".
} 
fighters necessarily violate humanitarian law; and (2) that civilian status is an advantage compared to combatant status.

Section 4.A below questions the first premise, while Section 4.B questions the second.

\section{Counterarguments}

\section{A. Circularity}

The first premise of the arguments cited in section 3 above, seems to be that the fighters in question violate their obligations under international humanitarian law by not complying with the requirements in Article 4(A)(2) of GC III. ${ }^{25}$ These requirements are that such fighters must be "commanded by a person responsible for his subordinates", have a "fixed distinctive sign", carry "arms openly", and comply with the "laws and customs of war" (see section 2).

Violating the first requirement is hardly compatible with constituting a "group" that can "belong" to a party to an IAC. This is therefore not relevant to the present discussion.

With regard to the following two requirements, combatants in IACs have an obligation to distinguish themselves from the civilian population (Article 44 (3) of AP I). This can be done by, e.g., wearing distinctive emblems and carrying arms openly. However, there is no such obligation for civilians, even those taking a direct part in hostilities. ${ }^{26}$ Saying that the fighters in question violate an obligation to distinguish

\footnotetext{
${ }^{25}$ Akande, supra note 22, at 184 speaks of "irregular groups that do not comply with the rules of international law concerning distinction, or with the laws and customs of more generally". ICRC, supra note 2, at 22 speaks of "irregular armed forces [that] fail to distinguish themselves [...], to carry their arms openly, or to conduct their operations in accordance with the laws and customs of war".

${ }^{26}$ There is an obligation not to "treacherously" kill or wound an adversary (Articles 8(2)(b)(xi) and 8(2)(e)(ix) of Rome Statute of the ICC. According to ICRC, supra note 2, at 85, killing without distinguishing oneself this "may" amount to perfidy. Even so, a prohibition of individual perfidious
} 
themselves presupposes that they are to be classified as combatants, which is precisely what is in question here. This argument thus presupposes the conclusion it is used to support, which makes it circular.

Regarding the final requirement, compliance with "laws and customs of war", combatants are bound by various rules international humanitarian law found in treaties and customary international law. Various violations of these rules, such as deliberately targeting civilians ${ }^{27}$ or using prohibited weapons ${ }^{28}$, are to be considered war crimes. ${ }^{29}$ Anyone, including civilians, can commit war crimes, ${ }^{30}$ and are thus bound by the corresponding "laws and customs of war" even though they do not have express obligations under the Geneva Conventions. It should be noted in this regard that there is no international law obligation on civilians not to take direct part in hostilities, ${ }^{31}$ so this is itself not a violation of the "laws and customs of war".

The conclusion is that only the requirement of complying with "the laws and customs war" in Article 4(A)(2) of GC III is relevant when discussing how to classify fighters who belong to a party to an IAC. In other words, the commission of war crimes by such fighters can be a relevant argument for not granting them legal benefits through

killings is conceptually distinct from an obligation of continuous distinction. This question is also different from whether international humanitarian law generally can be binding on non-State groups, as discussed by e.g. Kleffner, supra note 15, at 54-55.

${ }^{27}$ E.g. Article 51(2) of AP I; Article 13(2) of AP II; J.-M. Henckaerts and L. Doswald-Beck (eds.), supra note 19, at Rule 1

${ }^{28}$ E.g. Article 35(2) of AP I; J.-M. Henckaerts and L. Doswald-Beck (eds.), supra note 19, at Part IV ${ }^{29}$ Article 8 of Rome Statute; J.-M. Henckaerts and L. Doswald-Beck (eds.), supra note 19, at Rule 156.

${ }^{30}$ See e.g. ICRC, supra note 2, at 84; J.-M. Henckaerts and L. Doswald-Beck (eds.), supra note 19, at 573; K. Dörrmann, Elements of War Crimes under the Rome Statute of the International Criminal Court: Sources and Commentary (2003), at 34-37; A. Cassese and P. Gaeta, Cassese's International Criminal Law ( $3^{\text {rd }}$ edition, 2013), at 67; W. A. Schabas, The International Criminal Court: A Commentary on the Rome Statute (2010), at 209.

${ }^{31}$ ICRC, supra note 2, at 83. H.-P. Gasser and K. Dörmann, 'Protection of the Civilian Population' in D. Fleck (ed.), The Handbook of International Humanitarian Law 231 (3 $3^{\text {rd }}$ edition, 2013), at 232 write that "civilians have no such right to take a direct part in hostilities", but it is not clear whether they describe a prohibition against taking direct part or merely the absence of combatant immunity (see supra note 17). 
classification. The lack of a responsible commander, a failure to carry arms openly, and not wearing distinctive signs are not similarly relevant.

\section{B. Civilian status as a "reward"}

The other premise in the argument is that being classified as a civilian is to "gain additional protections from targeting" 32 and/or to be under "the more protective legal regime afforded to the civilian population",33 (see section 3 ).

The fighters in question are part of "militias" or "volunteer corps" that "belong" to a party to an IAC (Article 4(A)(2) of GC III). As such, if the fighters are classified as civilians, they will be members of groups that take a direct part in hostilities. Importantly, civilians taking a direct part in hostilities lose their civilian protection under the Additional Protocols, as per Article 43(3) of AP I and Article 13(3) of AP II.

The exact extent of this "loss" is debated. Civilians who repeatedly take direct part in hostilities can either lose their protection only for the duration of specific hostile actions, or also lose it for the time between such actions. ${ }^{34}$ For civilians who are members of groups that take direct part in hostilities, there seems to be a degree of consensus that there should be a loss of civilian protection for the duration of membership in said groups. This view is supported by the proponents of the mainstream arguments cited in section 2 above, ${ }^{35}$ as well as others ${ }^{36}$. If this is correct,

\footnotetext{
${ }^{32}$ Akande, supra note 22, at 184.

${ }^{33}$ ICRC, supra note 2, at 22.

${ }^{34}$ E.g. ICRC, supra note 2, at 70-71 supports the "revolving door" where protection is regained after each act, while Schmitt, supra note 23, at 35-38 and Y. Dinstein, The Conduct of Hostilities under the Law of International Armed Conflict ( $2^{\text {nd }}$ edition, 2010), at 147-149 oppose it.

${ }^{35}$ ICRC, supra note 2, at 71-73; Akande, supra note 22, at 188-191. These arguments concern civilian groups taking part in non-international armed conflicts. The ICRC's and Akande's schemes of classification leave no room for civilian groups in international armed conflicts. If they did, the reasoning that deprives partaking civilians of protection in non-international armed conflict would apply to international armed conflicts as well. The ICRC limits its argument to persons in a "continuous combat function".
} 
the classification of members of such groups as combatants or civilians has no bearing on their civilian protection. It will be absent in either case.

Whether participation in hostilities leads to a loss of protection is less clear under Geneva Convention IV (GC IV) ${ }^{38}$, which does not have a similar explicit provision in comparison to AP I and AP II. ${ }^{39}$

This means that groups that take a direct part in IACs have little or no "additional protection" to be gained from being classified as civilians rather than as combatants.

Moreover, being classified as a civilian entails the disadvantage of having and no entitlement to prisoner of war status, ${ }^{40}$ and no combatant immunity ${ }^{41}$. This can be significant for fighters who have committed regular acts of war and are captured by the enemy. ${ }^{42}$ However, this article concerns fighters who do not fulfil the requirement in Article 4(A)(2) of GC III, and thus should not have prisoner of war status or combatant immunity. ${ }^{43}$ That would mean that the question of classification is without consequence in this respect too.

\footnotetext{
${ }^{36}$ E.g. Schmitt, supra note 23, at 16-17, 22 and 24; and apparently Y. Dinstein, supra note 33, at 147149.

${ }^{38} 1949$ Geneva Convention Relative to the Protection of Civilian Persons in Time of War (Fourth Geneva Convention), 75 UNTS 287.

${ }^{39}$ E.g. Schmitt, supra note 23 , at 14-15 claims that GC IV protection is lost by taking direct part in hostilities; S. Borelli, 'Casting light on the legal black hole: International law and detentions abroad in the "war on terror", 87 International Review of the Red Cross 39 (2005), at 50-51 and ICRC, supra note 2, at 22 assume the opposite. Akande, supra note 22, at 184 seems to argue that GC IV can apply regardless of whether a fighter is classified as combatant or civilian, which should mean that the applicability GC IV will not be an argument for or against either classification.

${ }^{40}$ This can be inferred antithetically from Article 44(1) of AP I.

${ }^{41}$ See supra $\mathrm{n} 17$.

${ }^{42}$ E.g. the United States Department of Justice went to great lengths to find legal justifications for depriving Taliban fighters of prisoner of war status in a much-criticised 2002 memorandum (A. R. Gonzalez and W. J. Hayes, 'Re: Application of Treaties and Laws to al Qaeda and Taliban Detainees', in K.J. Greenberg and J. L. Dratel (eds.), The Torture Papers: The Road to Abu Ghraib 81 (2005), at Part III and IV).

${ }^{43}$ ICRC, supra note 2, at 22.
} 
In short, describing civilian status as an unqualified benefit for the fighters in questions seems to be too simplistic.

\section{A Possible Solution: “Armed Forces”}

Akande also argues that:

In any case, the category of persons being discussed (irregulars who are part of groups that belong to a State but who do not meet the conditions in article 4(A)(2) of GCIII) would be part of the armed forces of a State under article 43 of AP I and therefore would not be civilians under article 50(1). Article 43 defines the armed forces of a party as consisting "of all organized armed forces, groups and units which are under a command responsible to that Party for the conduct or its subordinates, even if that Party is represented by a government or an authority not recognized by an adverse Party.'It is recognized that this definition applies not only to regular forces but also to irregular forces which belong to a State. ${ }^{44}$

Accordingly, non-State groups taking part in IACs may be "armed forces" under Article 43 of AP I, and thus be combatants by virtue of Article 4(A)(1) of GC III. If so, applying Article 4(A)(2) of GC III is not necessary, and the issue discussed in the previous sections does not arise.

It is correct that Article 43(1) seems to cover more than the formal members of a State party's official military forces, as it also includes "groups and units" that are "under a command responsible" to the party. ${ }^{45}$ Thus Akande's argument holds for at least some groups that would otherwise have to be classified under Article 4(A)(2) of GC III.

\footnotetext{
${ }^{44}$ Akande, supra note 22, at 184 (footnote omitted).

${ }^{45}$ Akande, supra note 22, at 184. See also footnote 21 therein, which refers to Y. Sandoz, C. Swinarski and B. Zimmermann (eds.), Commentary to the Additional Protocols of 8 June 1977 to the Geneva Conventions of 12 August 1949 (1987), at paras. 1659-1674; see also M. Bothe, K. J. Partsch and W.
} A. Solf, New Rules for Victims of Armed Conflict: Commentary on the Two 1977 Protocols Additional to the Geneva Conventions of 1949 (1982), at 234; K. D. Mar, 'The Requirement of 'Belonging' under International Humanitarian Law', 21 European Journal of International Law 105 (2010), in footnote 51 therein refers to K. Ipsen, 'Combatants and Non-Combatants', in Fleck (ed.), The Handbook of International Humanitarian Law 85 ( $2^{\text {nd }}$ edition, 2008), at para. 304. 
Article 43 of AP I requires, however, that the groups in question are "under a command responsible" to a State party to the conflict. This may be a higher threshold than "belonging". If there are groups that "belong" to a party under Article 4(A)(2) of GC III without being under a "command responsible" to the party under Article 43 of AP I their classification cannot be resolved simply by reference to the latter. If so, the arguments outlined the previous sections are still necessary.

The exact content of the term "belong" is debated, but it is at least arguable that it represents a very low threshold, possibly requiring no more than tacit acceptance by the State party. ${ }^{46}$ This may be a lower threshold than being "under a command responsible" to a party to the conflict.

Article 91 of AP I provides that parties to the Protocol are "responsible for all acts committed by persons forming part of its armed forces". The term "armed forces" herein must correspond with the same term in Article 43 of that same Protocol. Thus, if all "belonging" fighters are classified as "armed forces", the State in question will be legally responsible for the actions of persons whose allegiance it has only tacitly accepted. The general customary international law rules on the responsibility of States is outlined in the ILC's draft articles on Responsibility of States for Internationally Wrongful Acts. ${ }^{47}$ Articles 4 to 11 require more than tacit acceptance for a State to be internationally responsible for the conduct of a non-State actor. ${ }^{48}$ Thus, for Akande's argument to work for all groups that may "belong" to a State party to an international armed conflict, Article 91 of AP I would have to be a lex specialis attribution rule. This is not impossible, ${ }^{49}$ but makes the argument somewhat less convincing than if it applied the regular customary law of State responsibility.

\footnotetext{
${ }^{46}$ ICRC, supra note 2, at 23; Mar, supra note 45, at 111-112.

${ }^{47}$ See S. Olleson, State Responsibility before International and Domestic Courts: The Impact and Influence of the ILC Articles (forthcoming 2016) about the treatment of the articles as customary law by various tribunals.

${ }^{48}$ Mar, supra note 45, at 120-121.

${ }^{49}$ Indeed, Article 55 of the Draft Articles on State Responsibility acknowledges the possibility of lex specialis rules.
} 
In short, it is possible to solve the issue raised in the previous sections on the basis of Article 43 of AP I. However, this does not align neatly with the requirement of a "command responsible" read in light of general international law of responsibility. Thus it is possible that some "belonging" groups may be outside the scope Article 43, which means that their classification cannot be resolved on the basis of that provision.

\section{Conclusion}

The classification of members of "militias" or "volunteer corps" that "belong" to a party to an IAC but do not meet the requirements in Article 4(A)(2) of GC III is debatable. It may well be that they should be classified as combatants rather than civilians, as argued by mainstream literature. However, existing arguments in favour of this solution are not sufficiently convincing: they are partly circular and may not take full account of the loss of civilian protection that results from direct participation in hostilities and the loss of prisoner of war status and combatant immunity that results from being classified as a civilian.

It is possible to resolve the issue by adopting a broad interpretation of "command responsible" in Article 43 of AP I, but more decisive arguments are needed before it can be seen as fully settled. 